\title{
The toxic Doppelganger: on the ionic and molecular mimicry of cadmium
}

\author{
Jagna Chmielowska-Bąk, Karolina Izbiańska and Joanna Deckert ${ }^{\bowtie}$ \\ Department of Plant Ecophysiology, Institute of Experimental Biology, Faculty of Biology, Adam Mickiewicz University, Poznań, Poland
}

\begin{abstract}
Cadmium is a toxic heavy metal which can cause numerous alterations in cell functioning. Exposure to cadmium leads to generation of reactive oxygen species, disorders in membrane structure and functioning, inhibition of respiration, disturbances in ion homeostasis, perturbations in cell division, and initiation of apoptosis and necrosis. This heavy metal is considered a carcinogen by the Agency for Toxic Substances and Disease Registry. At least some of the described toxic effects could result from the ability of cadmium to mimic other divalent ions and alert signal transduction networks. This review describes the role of cadmium mimicry in its uptake, reactive oxygen species generation, alterations in calmodulin, Wnt/ $\beta$-catenin and estrogen signaling pathways, and modulation of neurotransmission. The last section is dedicated to the single known case of a favorable function performed by cadmium mimicry: marine diatoms, which live in zinc deficient conditions, utilize cadmium as a cofactor in carbonic anhydrase - so far the only described cadmium enzyme.
\end{abstract}

Keywords: cadmium, mimicry, signaling, carbonic anhydrase

Received: 23 May, 2013; revised: 22 July, 2013; accepted: 21 August, 2013; available on-line: 29 August, 2013

\section{INTRODUCTION}

Cadmium causes deleterious effects in all organisms. Exposure to this heavy metal leads to oxidative stress, lipid peroxidation, alterations in ion homeostasis, DNA damage, and initiation of apoptotic and necrotic processes (Belyaeva et al., 2008; Gonçalves et al., 2009; Kippler et al., 2010; Lehotai et al., 2011; Matović et al., 2011; Pytharopoulou et al., 2011; Wang et al., 2011 ArasimowiczJelonek et al., 2012; Filipič, 2012; Liu et al., 2012). It has also been shown to exhibit carcinogenic and, depending on the concentration and analyzed species, pro- or antiinflammatory effects in mammalian cells (Joseph, 2009; Olszowski et al., 2012). In the case of plants cadmium toxicity manifests also in chlorophyll degradation, inhibition of photosynthesis and direction of the metabolism to the synthesis of protective compounds such as lignin or flavonoids (Küpper et al., 2007; Rascio et al., 2008; Pawlak-Sprada et al., 2011a; Pawlak-Sprada et al., 2011b; Sun et al., 2012). At least some of the toxic symptoms caused by cadmium stress could result from its ability to mimic essential ions.

Two types of mimicry can be distinguished at the cellular level: ionic and molecular. Ionic mimicry is the ability of unbound ions to mimic other ions or elements. An example of such a process is the entry of cadmium into the cell through transporters predestined for essen- tial elements. Molecular mimicry, in turn, consists in replacing other metals in biological molecules (Bridges \& Zalups, 2005). The cadmium molecular mimicry can alert signal transduction pathways and contribute to the $\mathrm{Cd}$ cytotoxicity in several ways. The substitution of essential ions by $\mathrm{Cd}^{2+}$ can lead to:

- release of the essential metals

The release of essential metals leads to an increase in their cellular concentrations. This phenomenon can have various consequences. Elevated levels of redox-active metals, such as iron and copper, can contribute to the generation of reactive oxygen species through Fenton and Haber-Weiss reactions. Release of calcium ions, in turn, can disrupt the cytoskeleton organization and $\mathrm{Ca}^{2+}$ mediated signaling.

- alterations in target molecule structure

Examples of alterations in the target molecule structure resulting from cadmium mimicry include disruption of $\beta$-catenin/cadherin complexes leading to the release of $\beta$-catenin and activation of $\mathrm{Wnt} / \beta$-catenin signaling, and replacement of $\mathrm{Mg}^{2+}$ in chlorophyll causing alterations in the structure and activity of photosystems.

- imitation of the action of the essential ion and activation of the target molecule

The binding of cadmium ions by a target protein can also mimic the action of other elements or molecules. Indeed, cadmium has been shown to imitate the function of $\mathrm{Ca}^{2+}$ in calmodulin and of estrogen in estrogen receptors.

The above examples of cadmium ionic and molecular mimicry and their influence on cellular signaling pathways are described in detail in the present review. The last section is dedicated to the so far unique example of a biological advantage of cadmium mimicry - the substitution for zinc ions in carbonic anhydrase in marine diatoms.

\section{CADMIUM UPTAKE}

Cadmium ions behave as "opportunistic hitch-hikers" - they enter cells through transporters and channels dedicated to essential divalent ions, such as $\mathrm{Ca}^{2+}, \mathrm{Fe}^{2+}$ and $\mathrm{Zn}^{2+}$. One of the candidates for Cd uptake are calcium channels. Treatment of plant or animal cells with calcium channel blockers, lanthanum and verapamil, caused augmentation in cadmium uptake (Braeckman et al., 1999; Kurtyka et al., 2011; Liu et al., 2012). Accord-

e-mail: joanna.deckert@amu.edu.p

Abbreviations: CA, carbonic anhydrase; GABA, gamma-aminobutyric acid; MLCK, myosin light chain kinase; ROS, reactive oxygen species; TCF/LEF-1, T-cell specific factors/lymphoid enhancer binding factor; Wnt, Wingless family. 
ingly, Madin-Darby canine kidney cells subjected to the action of a calcium channel activator, maitotoxin, accumulated more cadmium than the untreated cells (Olivi \& Bessler, 2000). Another putative route of cadmium cellular influx are transporters belonging to the ZIP family. A correlation between induced expression of ZIP10 and increased cadmium accumulation was observed in zebrafish (Chachene et al., 2011). An enhanced cadmium uptake has also been shown in mouse fetal fibroblast over-expressing ZIP8 and ZIP14 (Dalton et al., 2004; Girijashanker et al., 2008). There is evidence that the protective role of glutathione against cadmium stress depends on the down-regulation of ZIP8 gene expression (Aiba et al., 2008). In plants the IRT1, ZNT1 and ZNT2 transporters belonging to the ZIP family have been shown to play a role in cadmium uptake (Connolly et al., 2002; Mizuno et al., 2005; Lee \& An, 2009). The divalent cation transporters involved in cadmium uptake also include Nramp2 (alternative names: DCT1 or DMT1). Xenopus oocytes expressing human Nramp2 accumulated more cadmium than the control ones (Okubo et al., 2003). Cadmium mimicry of essential ions could not only facilitate the uptake of this heavy metal but also its translocation and intracellular trafficking. Experiments performed with the use of six lines of Arabidopsis thaliana mutants showed that transporters belonging to heavy metal $\mathrm{P}_{1 \mathrm{~B}}$-ATPases (HMA proteins), namely HMA2 and HMA4, were involved in Cd root-to-shoot translocation (Wong \& Cobett, 2003). Expression of AtHMA3 in a Cd-sensitive yeast strain, in turn, resulted in acquisition of tolerance to this heavy metal most probably through increased vacuolar sequestration (Gravot et al., 2004). Also Nramp proteins are involved in Cd accumulation and vacuolar compartmentalization in plants. The Nramp3 and Nramp4 transporters have been shown to reside in the vacuole membrane in two cadmium hyperaccumulators, Arabidopsis balleri and Thlaspi caerulescens. Moreover, a double nramp3nramp4 mutant of Arabidopsis thaliana was hypersensitive to Cd despite an unchanged intracellular Cd content (Oomen et al., 2009; Takahashi et al., 2011). These data show that mimicking divalent essential elements enables $\mathrm{Cd}^{2+}$ passing into animal and plant cells and its intracellular and long-distance translocation. In a cadmium-rich environment, $\mathrm{Cd}^{2+}$ can compete with other divalent elements for the transporters' binding sites. Therefore, the described ionic mimicry can lead to alterations in mineral homeostasis and distribution. Indeed, disorders in zinc, magnesium, calcium and potassium cellular balance have been reported in various organisms exposed to cadmium (Gonçalves et al., 2009; Kippler et al., 2010; Matović et al., 2011; Liu et al., 2012).

\section{GENERATION OF REACTIVE OXYGEN SPECIES}

One of the most common responses of organisms to cadmium exposure is generation of reactive oxygen species (Lehotai et al., 2011; Pytharopoulou et al., 2011; Vestena et al., 2011; Wang et al., 2011). Over-accumulation of ROS leads to oxidative stress which, in turn, causes lesions in various biological molecules such as peroxidation of lipids and oxidative damage of proteins and DNA. These lesions lead to membrane leakage, disturbed ion homeostasis, inactivation of enzymes, and increased rate of mutations (Scandalios, 2002). The reactive oxygen species generated in response to cadmium are also engaged in various signaling events (ChmielowskaBak \& Deckert, 2012). The Cd-dependent over-production of ROS can result from disturbances in antioxidant systems, increased activity of NADPH oxidase, and alterations of mitochondria (Garnier et al., 2006; RomeroPuertas et al., 2007; Gzyl et al., 2009; Ognjanović et al., 2010; Chen et al., 2011; Chou et al., 2012). An important source of ROS are Fenton and Haber Weiss reactions catalyzed by redox-active metals, such as iron and copper (Kehrer, 2000). Cadmium has no reduction-oxidation activity, but it can replace the redox-active metals in biological molecules and, as a consequence, increase the metals' intracellular levels. This hypothesis was confirmed by experiments performed on living cells and artificial lipid bilayers - liposomes. In those experiments cadmium caused peroxidation of lipid membranes in living cells, but not in liposomes, implying that cadmium alone is unable to cause an oxidative stress. It was therefore suggested that the peroxidation of membranes observed in living cells resulted from a Cd-dependent release of $\mathrm{Fe}^{2+}$ from biological molecules. That hypothesis was confirmed by two facts. Firstly, application of $\mathrm{Cd}^{2+}$ caused release of iron from ferritin and rat liver microsomes. Secondly, exogenous application of $\mathrm{Fe}^{2+}$ induced peroxidation of lipids in liposomes (Casalino et al., 1997). The ability of cadmium to substitute for iron has also been demonstrated in ferrodoxin (Bonomi et al., 1994). Therefore, it is possible that $\mathrm{Cd}$ contributes to oxidative stress through the release of redox-active metals resulting from their substitution in biological molecules.

\section{ACTIVATION OF WNT/ $\beta$-CATENIN SIGNALING}

In cells $\beta$-catenin can be found in membranes, cytoplasm and nucleus. In membranes this multifunctional protein forms complexes with E-cadherin and is engaged in cell-to-cell adhesion. The fate of cytoplasmic $\beta$-catenin strongly depends on the Wingless family (Wnt) ligands. As long as the Wnt signaling is switched off, cytoplasmic $\beta$-catenin is phosphorylated and directed for degradation. However, binding of the Wnt ligands to their receptors leads to the disruption of the complexes addressing $\beta$-catenin destruction. As a consequence, cytoplasmic $\beta$-catenin is translocated to the nucleus where it interacts with $\mathrm{T}$-cell specific factors/lymphoid enhancer binding factor (TCF/LEF-1). This, in turn, leads to the activation of Wnt signaling target genes which are involved in regulation of numerous developmental processes (Berthon et al., 2012). Exposure to cadmium can lead to abnormal activation of $\mathrm{Wnt} / \beta$-catenin signaling. It has been shown that cadmium alters the distribution of $\mathrm{N}$-cadherin, E-cadherin and $\beta$-catenin distribution in rat proximal tubule epithelium (Prozialeck et al., 2003). A breakdown of adherens junctions and redistribution of $\beta$-catenin in cells has also been observed in chicken embryos (Thompson et al., 2008). As E-cadherin has several $\mathrm{Ca}^{2+}$-binding sites, it has been suggested that $\mathrm{Cd}^{2+}$ displaces the $\mathrm{Ca}^{2+}$ in E-cadherins, which in turn leads to deformation of the E-cadherin/ $\beta$-catenin complexes and release of $\beta$-catenin to the cytoplasm and nucleus. This was confirmed by an experiment performed on rat proximal tubule cell cultures showing that the $\mathrm{Cd}$ dependent increase in cytoplasmic and nuclear $\beta$-catenin levels was independent of transcription and translation (Chakraborty et al., 2010). The increase of the $\beta$-catenin level in the nucleus in response to $\mathrm{Cd}$ administration leads to the activation of TCF4 transcription factor and induction of Wnt target genes, $c-M y c$, cyclin D1 and $A B C B 1$. The elevated expression of these genes can lead to enhanced cell proliferation and initiation of carcinogenesis (Chakraborty et al., 2010). 


\section{SIGNALING MEDIATED BY CALMODULIN}

Calmodulin is the main mediator of $\mathrm{Ca}^{2+}$ signaling. Binding of calcium ions to calmodulin causes changes in its conformation and exposure of hydrophobic residues in the central helix. The exposed residues are responsible for recognition and activation of various target proteins including kinases, ion channels, G-proteins, cytoskeleton elements, and transcription factors (Snedden \& Fromm, 1998; Clapham, 2007). Calmodulin is highly conserved and regulates numerous processes in all eukaryotic cells. Perhaps the most spectacular example of calmodulin's role are the beak shapes in Darwin's finches shown to be partially determined by the level of calmodulin expression (Abzhanov et al., 2006). Interestingly, calmodulin has also been shown to participate in the plant response to cadmium stress. Experiments on tobacco cell suspension culture show that activation of calmodulin is necessary for the $\mathrm{Cd}$-dependent stimulation of NADPH oxidase and generation of $\mathrm{H}_{2} \mathrm{O}_{2}$ (Olmos et al., 2003; Garnier et al., 2006). There is evidence that calcium can be replaced in calmodulin by other divalent ions with an affinity dependent on the ionic radius (Ouyang \& Vogel, 1998). Cadmium should be very efficient in substituting for calcium ions as the ionic radii of these elements are very similar $(0.97$ and $0.99 \AA$ respectively). Indeed, the ability of $\mathrm{Cd}^{2+}$ to bind to calmodulin has been shown by nuclear magnetic resonance (NMR), electrospray ionization mass spectrometry (ESI-MS), equilibrium gel filtration, flow microcalorimetry, and fluorescence techniques (Milos et al., 1989; Ouyang \& Vogel, 1998; Schirran \& Barran, 2009). Importantly, it has been shown that cadmium ions binds to calmodulin in its C-terminal sites III and IV, which also show the highest affinity for $\mathrm{Ca}^{2+}$ (Milos et al., 1989; Ouyang \& Vogel, 1998). The $\mathrm{Cd}^{2+}$ calmodulin complexes formed were able to activate a calmodulin target protein - myosin light chain kinase (MLCK) (Ouyang \& Vogel, 1998). Moreover, cadmium stimulated calcium-dependent phosphorylation of several substrates in the cytosolic fraction of rainbow trout gonadal cells (RTG-2) (Behra \& Gall, 1991). Interestingly, substitution of $\mathrm{Ca}^{2+}$ by $\mathrm{Cd}^{2+}$ leads to the inhibition of calmodulin activity in plants (Rivetta et al., 1997). The signaling functions of calmodulin strongly depend on the concentration of cytosolic $\mathrm{Ca}^{2+}$, which is strictly regulated by a complex machinery comprising of calcium channels, pumps and chelators (Clapham, 2007). The concentration of non-essential ions such as cadmium is not subjected to such a strict control, therefore the ability of $\mathrm{Cd}^{2+}$ to mimic $\mathrm{Ca}^{2+}$ functions in calmodulin can profoundly alter its signaling.

\section{MIMICRY OF ESTROGEN PATHWAY}

Recent research shows that Cd can modulate functioning of estrogen receptors (ERs) (Deegan et al., 2011). The ERs are located in the nucleus and are involved in regulation of gene expression in response to female sex steroid hormones, estrogens, such as $17 \beta$-estradiol $\left(E_{2}\right)$ (Brzozowski et al., 1997). Estrogen receptors contain conserved structural and functional domains for ligand binding (LBD), DNA binding (BD), and transcriptional activation (Matthews \& Gustafson, 2003). Several studies have demonstrated that cadmium is capable of mimicking the $\mathrm{E}_{2}$ action at the ligand binding domain of the ER (Garcia-Morales et al., 1994, Stoica et al., 2000; Martinez-Campa, 2008; Rider et al., 2009; Deegan et al., 2011). Estrogen-like effects of cadmium have been re- ported both in cell culture and in experimental animals. In mammalian cell culture, cadmium causes activation of intracellular signaling similar to estrogen, induction of the expression of estrogen target genes, stimulation of estrogen-specific proteins, and proliferation of estrogendependent cells (Garcia-Morales et al., 1994; Stoica et al., 2000; Wilson et al., 2004; Brama et al., 2007; MartinezCampa, 2008; Siewit et al., 2010; Deegan et al., 2011). In vivo studies in animal models, especially rats, have also provided strong evidence that Cd can mimic estrogen, specifically in organs and tissues known to be estrogen responsive. Exposure to cadmium increased uterine wet weight, promoted growth and development of the mammary glands and induced estrogen-regulated genes in ovariectomized animals (Johnson et al., 2003; AlonsoGonzález et al., 2007; Höfer et al., 2009; Liu et al., 2010; Penttinen-Damdimopoulou et al., 2010). The inhibition of those effects after the addition of antiestrogens further strengthens the conclusion that $\mathrm{Cd}^{2+}$ mimics estrogen signaling (Garcia-Morales et al., 1994; Johnson et al., 2003). Inappropriate stimulation of ERs activity by cadmium is believed to be an important factor contributing to the increasing incidence of cancer in industrialized countries. Recent epidemiological findings suggest an increased risk of hormone-dependent diseases, such as breast cancer, endometrial cancer, and endometriosis, after exposure to cadmium (Akesson et al., 2003; Thomson \& Bannigan, 2008; Strumylaite et al., 2010).

\section{CADMIUM AND NEUROTRANSMISSION}

Exposure to cadmium is associated with various neurotoxic symptoms. This heavy metal causes damage of rat and rabbit cerebellar cortices, affects functioning of voltage activated calcium and sodium channels in neurons, inhibits adenylate cyclase activity in the cerebrum, cerebellum and brain stems, modulates the release of inhibitory and excitatory neurotransmitters and inhibits the NO generating enzyme nitric oxide synthase (Sadiq et al., 2012). The involvement of cadmium in the modulation of nervous system functioning is recently becoming a subject of intense study. The neuromodulatory action of $\mathrm{Cd}^{2+}$ is based on its ability to replace $\mathrm{Zn}^{2+}$. Zinc is directly and indirectly involved in neurotransmission: it functions as neurotransmitter in a specific type of neurons called zinergic neurons, as well as a regulator of gamma-aminobutyric acid (GABA) release in GABAergic neurons (Colvin et al., 2003; Takeda, 2012). Zinc also modulates the activity of $\mathrm{P} 2 \mathrm{X}$ receptors which function as ATP-dependent cationic channels in various cell types including brain and peripheral nerves (Lorca et al., 2011). Experiments performed on Xenopus oocytes with injected $\mathrm{P}_{2} \mathrm{X}_{4}$ receptors showed that, out of eight metals assayed, only cadmium was able to mimic the action of zinc on the $\mathrm{P}_{2} \mathrm{X}_{4}$ receptors (Coddou et al., 2005). It is possible that cadmium mimics also other zinc functions in the nervous system. This hypothesis could be further strengthened by the fact that both $\mathrm{Zn}^{2+}$ and $\mathrm{Cd}^{2+}$ inhibit the release of GABA (Sadiq et al., 2012).

\section{CADMIUM AS ESSENTIAL METAL: CARBONIC ANHYDRASE}

Vertical profiles of $\mathrm{Cd}$ distribution in the ocean show that this metal, believed to be universally deleterious to organisms, has in fact a nutrient-like profile. Its concentration is extremely low in surface waters and increases in deep waters, similar to other biologically important 
nutrients, such as phosphate. This profile reflects the uptake of elements by phytoplankton at the surface and regeneration in the depths by remineralization of sinking organic matter (Park et al., 2007; Xu et al., 2008). The high fractionation of cadmium in organic matter clearly indicates that there must be an active $\mathrm{Cd}$ uptake system in marine organisms (Morel \& Price, 2003). Laboratory studies have established that $\mathrm{Cd}$ can be used as a co-factor in carbonic anhydrase (CA), particularly in the Cd-carbonic anhydrase found in the coastal diatom Thalassiosira weissflogii (CDCA1) (Lane et al., 2005) and categorized in a new zeta (५)-CA class (Lane \& Morel, 2000; McGinn \& Morel, 2008; Alterio et al., 2012). Carbonic anhydrase (EC 4.2.1.1) is a (primarily) zinc metalloenzyme that catalyses with an extremely high efficiency the reversible hydration of carbon dioxide, an essential reaction for many physiological processes such as respiration, ion transport, bone resorption, and photosynthesis (Ivanov et al., 2007; Supuran, 2010; Zhang et al., 2010). Diatoms, which are one of the most common types of phytoplankton and are responsible for $40 \%$ of the net marine primary production, use carbonic anhydrases (CAs) for acquisition of inorganic carbon (Park et al., 2007; McGinn \& Morel, 2008). In the ocean, where zinc is nearly absent, these diatoms use $\mathrm{Cd}$ as the catalytic metal atom in CDCA1 (Lane \& Morel, 2000; Park et al., 2007; Xu et al., 2008; Alteiro et al., 2012). This peculiar carbonic anhydrase is the first and hitherto the only known cadmium metalloenzyme and is responsible for the only known biologically beneficial cadmium-dependent reaction (Lane \& Morel, 2000; Xu et al., 2008). Although CDCA1 was initially isolated as a Cd enzyme, it is actually a cambialistic carbonic anhydrase that can use either $\mathrm{Zn}$ (II) or Cd (II) for catalysis and spontaneously exchange the two metals at its active centre. Indeed, a kinetic analysis has demonstrated that both single CA repeats and the full length enzyme exhibit high CA activity with either $\mathrm{Cd}$ or $\mathrm{Zn}$ as the catalytic metal, with only a slightly higher catalytic efficiency for the zinc forms. The Cd form of CDCA1 can therefore satisfy a substantial fraction of the needs of the fast growing diatoms $\mathrm{Xu}$ et al., 2008; Alteiro et al. 2012). Thus CDCA1 is an excellent example of adaptation to life in an environment containing a vanishingly small concentration of an essential metal. Furthermore, it has been suggested that the ability to use cadmium, an element known for its toxicity, probably gave a significant competitive advantage to diatoms in the ocean, which is poor in metals, and could have contributed to the evolutionary differentiation of diatoms during the Cenozoic Era and to the parallel decrease in atmospheric $\mathrm{CO}_{2}$ ( $\mathrm{Xu}$ et al., 2008).

\section{REFERENCES}

Abzhanov A, Kuo PK, Hartman C, Grant BR, Grant PR, Tabin CJ (2006) The calmodulin pathway and evolution of elongated beak morphology in Darwin's finches. Nature 442: 563-567.

Aiba I, Hossein A, Kuo MT (2008) Elevated GSH level increase cadmium resistance through down-regulation of Sp1-Dependent expression of the cadmium transporter ZIP8. Mol Pharmacol 74: 823-833.

Akesson A, Julin B, Wolk A (2008) Long-term dietary cadmium intake and postmenopausal endometrial cancer incidence: a populationbased prospective cohort study. Cancer Res 68: 6435-6441.

Alonso-González C, González A, Mazarrasa O, Güezmes A, SánchezMateos S, Martínez-Campa C, Cos S, Sánchez-Barceló EJ, Mediavilla MD (2007) Melatonin prevents the estrogenic effects of subchronic administration of cadmium on mice mammary glands and uterus. J Pineal Res 42: 403-410.

Alteiro V, Langella E, Viparelli F, Vullo D, Ascione G, Dathan NA, Morel FMM, Supuran CT, De Simone G, Monti SM (2012) Structural and inhibition insights into carbonic anhydrase CDCA1 from the marine diatom Thalassiosira weissflogi. Biochimie 94: 1232-1241.
Arasimowicz-Jelonek M, Floryszak-Wieczorek J, Deckert J, RucińskaSobkowiak R, Gzyl J, Pawlak-Sprada S, Abramowski D, Jelonek T, Gwóźdź EA (2012) Nitric oxide implication in cadmium-induced programmed cell death in roots and signaling response of yellow lupine plants. J Plant Physiol Bioch 58: 124-134.

Behra R, Gall R (1991) Calcium/clamodulin-dependent phosphorylation and the effect of cadmium in cultured fish cells. Comp Biochem Phys C 100: 191-195.

Belyaeva EA, Dymkowska S, Więckowski MR, Wojtczak L (2008) Mitochondria as an important target in heavy metal toxicity in rat hepatoma AS-20D cells. Toxicol Appl Pharm 231: 34-42.

Berthon A, Martinez A, Bertherat J, Val P (2012) Wnt/ $\beta$-catenin signalling in adrenal physiology and tumour development. Mol Cell Endocrinol 351: 87-95.

Bonomi F, Ganadu ML, Lubinu G, Pagani S (1994) Reversible and non-denaturating replacement of iron by cadmium in Clostridium pasteurianum ferrodixin. Eur J Biochem 222: 639-644.

Braeckman B, Samgghe G, Brutsaert N, Cornelis N, Raes H (1999) Cadmium uptake and defense mechanisms in insect cells. Environ Res Section A 80: 231-243.

Brama M, Gnessi L, Basciani S, Cerulli N, Politi L, Spera G, Mariani S, Cherubini S, d'Abusco AS, Scandurra R, Migliaccio S (2007) Cadmium induces mitogenic signaling in breast cancer cell by an ER alpha-dependent mechanism. Mol Cell Endocrinol 264: 102-108.

Bridges CC, Zalups RK (2005) Molecular and ionic mimicry and the transport of toxic metals. Toxicol Appl Pharm 204: 274-308.

Brzozowski AM, Pike AC, Dauter Z, Hubbard RE, Bonn T, Engstrom O, Ohman L, Greene GL, Gustafsson JA, Carlquist M (1997) Molecular basis of agonism and antagonism in the oestrogen receptor. Nature 389: 753-758.

Casalino E, Sblano C, Landriscina C (1997) Enzyme activity alteration by cadmium administration to rats: the possibility of iron involvement in lipid peroxidation. Arch Biochem Biophys 346: 171-179.

Chakraborty PK, Lee W-K, Molitor M, Wolff NA, Thévenod F (2010) Cadmium induces Wnt signaling to upregulate proliferation and survival genes in sub-confluent kidney proximal tubule cells. Mol Cancer 9: 102 .

Chauchene L, Banni M, Kerkeni A, Saild K, Messaoudi I (2011) Cadmium-induced ovarian pathophysiology is mediated by change in gene expression pattern of zinc transporters in zebrafish (Danio rerio). Chem-Biol Interact 193: 172-179.

Chen S, Xu B, Liu L, Luo Y, Zhou H, Chen W, Shen T, Han X, Kontes CD, Huang S (2011) Cadmium induction of reactive oxygen species activates the mTOR pathways, leading to neuronal cell death. Free Radical Biol Med 50: 624-632.

Chmielowska-Bak J, Deckert J (2012) A common response to common danger? Comparison of animal and plant signaling pathways involved in cadmium sensing. J Cell Commun Signal 6: 191-204.

Chou T-S, Chao Y-Y, Kao CH (2012) Involvement of hydrogen peroxide in heat shock- and cadmium-induced expression of ascorbate peroxidase and glutathione reductase in leaves of rice seedlings. $J$ Plant Physiol 169: 478-486.

Clapham DE (2007) Calcium signaling. Cell 131: 1047-1058.

Coddou C, Lorca RA, Acuña-Castillo C, Grauso M, Rassendren F, Huidobro-Toro JP (2005) Heavy metals modulate the activity of the purinergic P2X receptor. Toxicol Appl Pharm 202: 121-131.

Colvin RA, Fontaine CP, Laskowski M, Thomas D (2003) $\mathrm{Zn}^{2+}$ transporters and $\mathrm{Zn}^{2+}$ homeostasis in neurons. Eur J Pharmacol 476: 171185.

Connolly EL, Fett JP, Guerinot ML (2002) Expression of the IRT1 metal transporter is controlled by metals at the levels of transcript and protein accumulation. Plant Cell 14: 1347-1357.

Dalton TP, He L, Wang B, Miller ML, Jin L, Stringer KF, Chang X, Baxter CS, Nebert DW (2005) Identification of mouse SLC39A8 as the transporter responsible for cadmium-induced toxicity in testis. Proc Natl Acad Sci USA 102: 3401-3406.

Deegan BJ, Bona AM, Bhat V, Mikles DC, McDonald CD, Seldeen KL, Farooq A (2011) Structural and thermodynamic consequences of the replacement of zinc with environmental metals on estrogen receptor $\alpha$-DNA interactions. I Mol Recognit 24: 1007-1017.

Filipič M (2012) Mechanisms of cadmium induced genomic instability. Mutat Res 733: 69-77.

Garcia-Morales P, Aceda M, Kenney N, Kims N, Salomon DS, Gottardisn MM, Solomonn HB, Shollern PF, Jordan C, Martin MB (1994) Effect of cadmium on estrogen receptor levels and estrogeninduced responses in human breast cancer cells. J Biol Chem 269: 16896-16901.

Garnier L, Simon-Plas F, Thuleau P, Agnel J-P, Blein J-P, Ranjeva R, Montillet J-L (2006) Cadmium affects tobacco cells by a series of three waves of reactive oxygen species that contribute to cytotoxicity. Plant Cell Environ 29: 1956-1969.

Girijashanker K., He L, Soleimani M, Reed JM, Li H, Liu Z, Wang B, Dalton TB, Nebert DW (2008) Slc39a14 gene encodes ZIP14, a metal/bicarbonate symporter: similarities to the ZIP8 transporter. Mol Pharmacol 73: 1413-1423. 
Gonçalves JF, Antes FG, Maldaner J, Pereira LB, Tabaldi LA, Rauber R, Rossato LV, Bisognin DA, Dressler V, Flores EM, Nicoloso FT (2009) Cadmium and mineral nutrient accumulation in potato plantlets grown under cadmium stress in two different experimental culture conditions. Plant Physiol Bioch 47: 814-821.

Gravot A, Lieutaud A, Verret F, Auroy P, Vavasseur A, Richaud P (2004) AtHMA3, a plant $\mathrm{P}_{1 \mathrm{~B}}$-ARPase, functions as a $\mathrm{Cd} / \mathrm{Pb}$ transporter in yeast. FEBS Lett 561: 22-28.

Gzyl J, Rymer K, Gwóźdź EA (2009) Differential response of antioxidant enzymes to cadmium stress in tolerant and sensitive cell line of cucumber (Cucumis sativus L.). Acta Biochim Pol 56: 723-727.

Höfer PN, Diel P, Wittsiepe J, Wilhelm M, Degen GH (2009) Doseand route-dependent hormonal activity of the metalloestrogen cadmium in the rat uterus. Toxicol Lett 191: 123-131.

Ivanov BN, Ignatova LK, Romanova AK (2007) Diversity in forms and functions of carbonic anhydrase in terrestrial higher plants. Rus J Plant Phys 52: 143-162.

Johnson MD, Kenny N, Stoica A, Hilakivi-Clarke L, Singh B, Chepko G, Clarke R, Sholler PF, Lirio AA, Foss C, Reiter R, Trock B, Paik $\mathrm{S}$, Martin MB (2003). Cadmium mimics the in vivo effects of estrogen in the uterus and mammary glands. Nat Med 9: 1081-1084.

Joseph P (2009) Mechanisms of cadmium carcinogenesis. Toxicol Appl Pharmacol 238: 272-279.

Kehrer JP (2000) The Haber-Weiss reaction and mechanism of toxicity. Toxicology 149: 43-50.

Kippler M, Hoque AMW, Raqib R, Öhrvic H, Ekström E-C, Vahter M (2010) Accumulation of cadmium in human placenta interacts with the transport of micronutrients to the fetus. Toxicol Lett 192 162-168.

Kurtyka R, Kita A, Karcz W (2011) Fusicoccim counteracts the toxic effect of cadmium on the growth of maize coleoptile segments. Arch Environ Contam Toxicol 61: 568-577.

Küpper H, Parameswaran A, Leitenmaier B, Trílek M, Šetlik I (2007) Cadmium-induced inhibition of photosynthesis and long-term acclimation to cadmium stress in the hyperaccumulator Thlaspi caerulescens. New Phytol 175: 655-674.

Lane TW, Morel FMM (2000) A biological function for cadmium in marine diatoms. Proc Natl Acad Sci USA 97: 4627-4631.

Lane TW, Saito MA, George GN, Pickering IJ, Prince RC, Morel FM (2005) Biochemistry: a cadmium enzyme from a marine diatom. $\mathrm{Na}$ ture 435: 42.

Lee S, An G (2009) Over-expression of OsIRT1 leads to increased iron and zinc accumulation in rice. Plant Cell Environ 32: 408-416.

Lehotai N, Petö A, Bajkán S, Erdei L, Tari I, Kolbert Z (2011) In vivo and in situ visualization of early physiological events induces by heavy metals in pea root meristem. Acta Physiol Plant 33: 2199-2207.

Li L, Liu X, Peijnenburg WJGM, Zhao J, Chen X, Yu J, Wu H (2012) Pathways of cadmium fluxes in the root of halophyte Suaeda salsa. Ecotox Environ Safe 75: 1-7.

Liu C-H, Huang W-D, Kao CH (2012) The decline in potassium concentration is associated with cadmium toxicity in rice seedlings. Acta Physiol Plant 34: 495-502.

Liu J, Huang H, Zhang W, Li H (2010) Cadmium induced increase uterine wet weight and its mechanism. Birth Defects Res 89: 43-49.

Lorca RA, Rozas C, Loyola S, Moreira-Ramos S, Zeise ML, Kirkwood A, Huidobro-Toro JP, Morales B (2011) Zinc enhances long-term potentiation through P2X receptor modulation in the hippocampal CA1 region. Eur J Neurosci 33: 1175-1185.

Martínez-Campa CM, Alonso-González C, Mediavilla MD, González SCA, Sanchez-Barcelo EJ (2008) Melatonin down-regulates hTERT expression induced by either natural estrogens (17b-estradiol) or metalloestrogens (cadmium) in MCF-7 human breast cancer cells. Cancer Lett 268: 272-277.

Matović V, Buha A, Bulat Z, Dukić-Ćosić D (2011) Cadmium toxicity revised: focus on oxidative stress induction and interaction with zinc and magnesium. Arb Hig Rada Toksikol 62: 65-76.

Matthews J, Gustafson JA (2003) Estrogen signaling: a subtle balance between ER-alpha and ER-beta. Mol Intervent 3: 281-292.

McGinn PJ, Morel FMM (2008) Expression and regulation of carbonic anhydrases in the marine diatom Thalassiosira pseudonana and in natural phytoplankton assemblages from Grat Bay. Phys Plant 133: 78-91.

Milos M, Schaer J-J, Comte M, Cox JA (1989) Evidence for four capital and six auxiliary cation-binding sites on calmodulin: divalent cation interactions monitored by direct binding and microcalorimetry. $J$ Inorg Biochem 36: 11-25.

Mizuno T, Usui K, Horie K, Nosaka S, Mizuno N, Obata H (2005) Cloning of three ZIP/Nramp transporter genes from $\mathrm{Ni}$ hyperaccumulator Thlaspi japonicum and their $\mathrm{Ni}^{2+}$-transport abilities. Plant Physiol Bioch 43: 793-801.

Morel FMM, Price NM (2003) The biogeochemical cycles of trace metals in the oceans. Science 300: 944-947.

Ognjanović BI, Marković SD, Dordević NZ, Trbojević IS, Štajn AŠ, Saičić ZS (2010) Cadmium-induced lipid peroxidation and changes in antioxidant defense system in the rat testes: Protective role of coenzyme Q10 and Vitamin E. Reprod Toxicol 29: 191-197.
Okubo M, Yamada K, Hosoyamada M, Shibasaki T, Endou H (2003) Cadmium transport by human Nramp2 expressed in Xenopus laevis oocytes. Toxicol Appl Pharm 187: 162-167.

Olivi L, Bessler J (2000) Maitotoxin stimulates Cd influx in MadinDarby kidney cells by activating Ca-permeable cation channels. Cell Calcium 27: 187-193.

Olmos E, Martínez-Solano JR, Piqueras A, Hellín E (2003) Early steps in the oxidative burst induced by cadmium in cultured tobacco cells (BY-2 line). J Exp Bot 54: 291-301.

Olszowski T, Baranowska-Bosiacka I, Gutowska I, Chlubek D (2012) Pro-inflammatory properties of cadmium. Acta Biochim Pol 59: 475482.

Oomen RJF, Wu J, Leliévre F, Blanchet S, Richaud P, Barbier-Brygoo H, Aarts MGM, Thomine S (2009) Functional characterization of NRAMP3 and NRAMP4 from the metal hyperaccumulator Thlaspi caerulenscens. New Phytol 181: 637-650.

Ouyang H, Vogel HJ (1998) Metal ion binding to calmodulin: NMR and fluorescence studies. BioMetals 11: 213-222.

Park H, Song B, Morel FM (2007) Diversity of the cadmium-containing carbonic anhydrase in marine diatoms and natural waters. Environ Microbiol 9: 403-413.

Pawlak-Sprada S, Arasimowicz-Jelonek M, Podgórska M, Deckert J (2011a). Activation of phenylpropanoid pathway in legume plants exposed to heavy-metals. Part I. Effect of cadmium and lead on phenylalanine ammonia-lyase gene expression, enzyme activity and lignin content. Acta Biochim Pol 58: 211-216.

Pawlak-Sprada S, Stobiecki M, Deckert J (2011b) Activation of phenylpropanoid pathway in legume plants exposed to heavy-metals. Part II. Profiling of isoflavonoids and their glycoconjugates induced in roots of lupine (Lupinus luteus) seedlings treated with cadmium and lead. Acta Biochim Pol 58: 217-223.

Prozialeck WC, Lamar PC, Lynch SM (2003) Cadmium alerts the localization of $N$-cadherin, and $\beta$-catenin in the proximal tubule epithelium. Toxicol Appl Pharm 189: 180-195.

Pytharopoulou S, Grintzalis K, Sazakli E, Leotsindis M, Georgiou CD, Kalpaxis DL (2011) Translation responses and oxidative stress of mussels experimentally exposed to $\mathrm{Hg}, \mathrm{Cu}$ and $\mathrm{Cd}$ : pattern does not fit at all. Aquat Toxicol 105: 157-165.

Rascio N, Vecchia FD, Rocca N., Barbato R, Pagliano C, Raviolo M, Gonnelli C, Gabbrielli R (2008) Metal accumulation and damage in rice (cv. Vialone nano) seedlings exposed to cadmium. Environ Exp Bot 62: 267-278.

Rider CV, Hartig PC, Cardon MC, Wilson VS (2009) Comparison of chemical binding to recombinant fathead minnow and human estrogen receptors alpha in whole cell and cell-free binding assays. Environ Toxicol Chem 28: 2175-2181.

Rivetta A, Negrini N, Cocucci M (1997) Involvement of $\mathrm{Ca}^{2+}$-calmodulin in $\mathrm{Cd}^{2+}$ toxicity during the early phases of radish (Raphanus sativus L.) seed germination. Plant Cell Environ 20: 600-608.

Romero-Puertas MC, Corpas F, Rodríguez-Serrano M, Gómez M, del Río LA, Sandalio LM (2007) Differential expression and regulation of antioxidant enzymes by cadmium in pea plants. I Plant Physiol 164: $1346-1357$

Sadiq S, Ghazala Z, Chowdhury A, Büsselberg D (2012) Metal toxicity at the synapse: presynaptic, postsynaptic and long-term effects. Toxicol doi: $10.1155 / 2012 / 132671$

Scandalios JG (2002) The rise of ROS. Trends Biochem Sci 27: 483-486.

Schirran SL, Barran PE (2009) The use of ESI-MS to probe the binding of divalent cations to calmodulin. I Am Soc Mass Spectr 20: 1159-1171.

Siewit LC, Gengler B, Vegas E, Puckett R, Louie MC (2010) Cadmium promotes breast cancer cell proliferation by potentiating the interaction between ER alpha and c-Jun. Mol Endocrinol 24: 981-992.

Snedden WA, Fromm H (1998) Calmodulin, calmodulin-related proteins and plant responses to the environment. Trends Plant Sci 3: 299-304

Stoica A, Katzenellenbogen BS, Martin MB (2000) Activation of estrogen receptor-alpha by the heavy metal cadmium. Mol Endocrinol 14: $545-553$.

Strumylaite L, Bogusevicius A, Abdrachmanovas O, Baranauskiene D, Kregzdyte R, Pranys D, Poskiene L (2010) Cadmium concentration in biological media of breast cancer patients. Breast Cancer Res Treat 125: $511-517$

Sun Z, Wang L, Chen M, Wang L, Liang C, Zhou Q, Huang X (2012) Interactive effects of cadmium and acid rain on photosynthetic light reaction in soybean seedlings. Ecotox Environ Safe 79: 62-68.

Supuran CT (2010) Carbonic anhydrase inhibitor. Bioorg Med Chem Lett 20: 3467-3474.

Takahashi R, Ishimura Y, Senoura T, Shimo H, Ishiwaka S, Arao T, Nakanishi H, Nishizawa NK (2011) The OsNRAMP1 iron transporter is involved in Cd accumulation in rice. I Exp Bot 62: 4843 4850

Takeda A (2012) Zinc signaling in the hippocampus and its relation to pathogenesis of depression. I Trace Elem Med Bio 26: 80-84.

Thompson J, Bannigan J (2008) Cadmium: toxic effects on the reproductive system and the embryo. Reprod Toxicol 25: 304-315. 
Thompson J, Wong L, Lau PS, Bannigan J (2008) Adherens junction breakdown in the periderm following cadmium administration in the chick embryo: distribution of cadherins and associated molecules. Reprod Toxicol 25: 39-46.

Vestena S, Cambraia J, Ribeiro C, Oliveira JA, Oliva MA (2011) Cadmium induced oxidative stress and antioxidative enzyme response in Water Hyacinth and Salvinia. Braz J Plant Physiol 23: 131-139.

Wang L, Wang H, Li J, Chen D, Liu Z (2011) Simultaneous effect of lead and cadmium on primary cultures of rat proximal tubular cells: interaction of apoptosis and oxidative stress. Arch Environ Contam Toxicol 61: 500-511.

Wilson VS, Bobseine K, Gray LE (2004) Development and characterization of a cell line that stably expresses an estrogen-responsive lu- ciferase reporter for the detection of estrogen receptor agonist and antagonists. Toxicol Sci 81: 69-77.

Wong CKE, Cobett CS (2003) HMA P-type ATPases are the major mechanism for root-to-shoot Cd translocation in Arabidopsis thaliana. New Phytol 181: 71-78.

Xu Y, Feng L, Jeffrey PD, Shi Y, Morel FMM (2008) Structure and metal exchange in the cadmium carbonic anhydrase of marine diatoms. Nature 452: 56-61.

Zhang BY, Yang F, Wang CC, Peng G (2010) Cloning and quantitative analysis of the carbonic anhydrase gene from Porpbyra yezoensis. J Pbycology 46: 290-296. 